\title{
Entrepreneurial intention of undergraduate students of G. B. Pant University of Agriculture and Technology, Pantnagar
}

\author{
Amita Yadav* and S.K. Kashyap \\ Department of Agricultural Communication, Govind Ballabh Pant University of Agriculture and Technology, \\ Pantnagar- 263145 (Uttarakhand), INDIA \\ *Corresponding author. E-mail: amitayadavgbpuat@gmail.com \\ Received: October 7, 2016; Revised received: March 18, 2017; Accepted: July 28, 2017
}

\begin{abstract}
Entrepreneurship can positively impact human resource market by creating employment and economic opportunity, something that is of urgent need. Agriculture sector has immense untapped potential and huge business prospects for young entrepreneurs. Thus, to have an insight into these issues present study was undertaken to find out the socioeconomic, personal and psychological characteristics of undergraduate students along with their entrepreneurial intention. The study was conducted at College of Agriculture, G.B.P.U.A. and T. Pantnagar. Fifty five students from each, third year and final year of B.Sc. Agriculture were selected as respondents through simple random sampling technique using chit method. Analytical research design was used for the present study. Detailed pre-tested questionnaire was administered to 110 respondents for collection of data. Findings of the study revealed that majority of the respondents $(60.91 \%$ ) belonged to middle age group and were female (55.55\%), belonged to general caste $(60.91 \%)$ and had received their basic education in English $(72.73 \%)$. Regarding the entrepreneurial intention of undergraduate students of agriculture, it was found that majority of the respondents (59.09\%) had moderate level of entrepreneurial intention, while $23.64 \%$ of the respondents had low entrepreneurial intention and only $17.27 \%$ students had high entrepreneurial intention. The findings of this study may help all stakeholders (policy makers, researchers, private institutions, entrepreneurship educators and youth development practitioners) who are concerned with developing youth entrepreneurship in the country.
\end{abstract}

Keywords: Agriculture, Economic, Entrepreneurial Intention, Entrepreneurship, Human resource

\section{INTRODUCTION}

Entrepreneurs play a very important role in the economic development of any nation. Entrepreneurship on small scale is the only solution to the problems of unemployment, proper utilization of both human and material resources and improving the living conditions of the poor masses. During the last three decades, many countries of the world have experienced the need for entrepreneurship. Entrepreneurship development has been accepted as a strategy to achieve the twin objectives of promotion of employment opportunities, particularly among the educated unemployed youth and also for rapid industrialization of the economy (Mali, 2000).

Creating jobs for young generation is a major challenge around the world and the burden of unemployment has disproportionately fallen on the youth. The prolonged job crisis has forced the current generation of youth to be less selective about the type of job they are prepared to accept. In this respect, entrepreneurship emerges as an answer to crisis of rising unemployment. In a country like India with vast population directly dependent on agriculture as their primary occupation, agricultural entrepreneurship paves a way to- wards enormous opportunity of youth involvement in economically sustainable livelihood options. Moreover, agricultural development is an important foundation for the economic development of any country and the agricultural sector is undoubtedly the prime area of concentration for economic progress. Agriculture and allied industries have potential to provide ample opportunities for young entrepreneurs not only for a good income but also for a good standing in the society. There is a need for awareness and adequate inputs by the government to ensure an increased participation of youth in agricultural entrepreneurship ventures.

The global youth unemployment rate was 12.6 per cent in 2013. In absolute terms 73 million young people are estimated to be unemployed in 2013. Globally, the ratio of youth to adult unemployment rates is estimated to be 2.7 in 2013.It means that young people are three times more likely than adults to be unemployed (ILO, 2013).

India has the largest youth population in the world. About 70 per cent of India's population is below the age of 35 years, making India the youngest nation in the world. According to some estimates, the proportion of population under 25 years in India is 51 per cent and the proportion under 35 is about 66 per cent. Some 
experts refer to this large proportion of youth as "demographic dividend" because greater proportion of the population is young and in the working age-group which can lead to economic growth. However, out of the youth population of 460 million, only 333 million youth in India are literate and unemployment rate is highest (10.6 per cent) among youth (Top of NYP, 2012).

Almost every graduate looks for a white-collar job preferably in public sector. Job opportunities in government sector are shrinking faster than the number of graduates coming out of educational institutions. According to an estimate (IAMR, 2001), 43\% of the graduates and $23 \%$ of postgraduates (M.Sc.) find difficulty in accessing gainful employment. Again, entrepreneurship may emerge as a practical and viable solution to this problem.

Entrepreneurship can positively impact human resource market by creating employment and economic opportunity, something that is of urgent need. Agriculture sector has immense untapped potential and huge business prospects for young entrepreneurs. The active support of government policies and programmes in this respect makes entrepreneurship in agriculture even more lucrative. Therefore, this sector may emerge as a potential answer to the problem of unemployment for agricultural graduates of the country. There is a pressing need to change the outlook of youth towards agriculture sector so that they may look towards it as prospective opportunity for self-employment. Looking into the employment scenario of agricultural graduates of previous years, it can be concluded that negligible number of agricultural graduates are opting for agricultural entrepreneurship as a career prospect. In view of the above, the objective of the research is to study the entrepreneurial intention of undergraduate students of agriculture.

\section{MATERIALS AND METHODS}

Research methodology: The College of Agriculture, G. B. Pant University of Agriculture and Technology, Pantnagar, Udham Singh Nagar district of Uttarakhand state was purposively selected which constituted the locale of the present study because the locale in which this study was conducted is the premier agricultural institute of the country which is first Agriculture University established in India and takes pride as initiator of Practical Crop Production course in order to give direct experience in sowing, cultivation, and cost benefit analysis of crops. Students not only earn while they learn but are also exposed to various facets of rural life and work situation through attachment to village and agro-industrial organization as well as participation in plant clinic laboratories and field work. The present study was done at College of Agriculture. Fifty per cent students from each, third and fourth year of B.Sc. Agriculture were selected as respondents through Sim- ple Random Sampling Technique by using chit method to draw sample. Total 110 respondents were selected for collection of data. Analytical research design was used for the present study. Detailed pre-tested questionnaire was administered to respondents as per (Kothari, (1990).

After deep analysis of various theories and review of literature on available career prospects, age, gender, caste, medium of basic education, academic performance, family size, family type, family background, total family income, occupation of head of the family, self-confidence, achievement motivation, innovativeness and risk taking ability were taken as independent variables in the present study. Entrepreneurial intention of undergraduate students of agriculture was taken as the dependent variable (Fatoki 2010).

\section{RESULTS AND DISCUSSION}

Sample characteristics: The average age of students was 21.1 years and the range of students' age was in between 19 to 24 years. Majority of respondents (60.91 per cent) belonged to middle age group. The results regarding the gender of the respondents indicate that majority of the respondents (55.55 per cent) were female and the male population was 45.45 per cent. This is due to the 30 per cent women quota policy of Uttarakhand government that females are in majority in agriculture degree programme. This is similar to the findings from other studies in Iran where it was found that majority of respondents were female (Shiri et al, 2012; and Movahedi and Chakhtabian, 2013). It was observed that more than half of the respondents (60.91 per cent) belonged to general caste. Thus, it can be concluded that majority of the students enrolled to the University belonged to General caste. It was found that majority of the respondents (72.73 per cent) had received instruction in English, while 27.27 percent of students were from Hindi medium. The findings clearly depict that majority of the respondents (63.64 per cent) had average Cumulative Grade Point Average (CGPA). This shows that as students are good at studies so they are willing to pursue their career in academics and do not want to go for self-employment. It was observed that the per cent age of respondents living in nuclear family (81 per cent) was much higher than the respondents from joint families (19 per cent) and majority of the respondents ( 84.55 per cent) came from medium size families. Majority of respondents had their residences located in urban area (52.73 per cent) and 71.82 per cent belonged to families from middle income group category. High income group and low income group respondents comprised of 14.54 per cent and 13.64 per cent, respectively. It was observed that occupation of head of the family of majority of respondents (66.36 per cent) was service followed by 14.55 per cent in business and 11.82 per cent were engaged in cultivation. Remaining 7.27 per cent were 
Table 1. Characteristics of undergraduate students of agriculture.

\begin{tabular}{|c|c|c|}
\hline Variables & Frequency & Percentage \\
\hline \multicolumn{3}{|l|}{ Age } \\
\hline Young (19-20 years) & 24 & 20.87 \\
\hline Middle (21-22 years) & 77 & 66.96 \\
\hline Old (23-24 years) & 11 & 10 \\
\hline \multicolumn{3}{|l|}{ Gender } \\
\hline Male & 50 & 45.45 \\
\hline Female & 60 & 54.55 \\
\hline \multicolumn{3}{|l|}{ Caste } \\
\hline General & 67 & 60.91 \\
\hline Other Backward Castes & 17 & 15.45 \\
\hline Schedule Castes/Schedule Tribes & 26 & 23.64 \\
\hline \multicolumn{3}{|l|}{ Medium of basic education } \\
\hline Hindi & 30 & 27.27 \\
\hline English & 80 & 72.73 \\
\hline \multicolumn{3}{|l|}{ Academic performance } \\
\hline Low (up to 6.99) & 17 & 14.54 \\
\hline Average (7-7.87) & 70 & 63.64 \\
\hline $\operatorname{High}(>7.87)$ & 24 & 21.82 \\
\hline \multicolumn{3}{|l|}{ Family type } \\
\hline Nuclear & 89 & 81 \\
\hline Joint & 21 & 19 \\
\hline \multicolumn{3}{|l|}{ Family size } \\
\hline Small (up to 3 members) & 6 & 5.45 \\
\hline Medium (4-10 members) & 93 & 84.55 \\
\hline Large ( $>10$ members) & 11 & 10 \\
\hline \multicolumn{3}{|l|}{ Family background } \\
\hline Rural & 52 & 47.27 \\
\hline Urban & 58 & 52.73 \\
\hline \multicolumn{3}{|l|}{ Total family income } \\
\hline Low (up to Rs.189824) & 15 & 13.64 \\
\hline Middle(Rs.189825-581103) & 79 & 71.82 \\
\hline High (>Rs.581103) & 16 & 14.54 \\
\hline \multicolumn{3}{|l|}{ Occupation of head of the family } \\
\hline Labour & Nil & 0 \\
\hline Caste occupation & Nil & 0 \\
\hline Business & 16 & 14.55 \\
\hline Independent profession & 8 & 7.27 \\
\hline Cultivation/farming & 13 & 11.82 \\
\hline Service & 73 & 66.36 \\
\hline \multicolumn{3}{|l|}{ Self-confidence } \\
\hline Low (up to 24) & 18 & 16.36 \\
\hline Moderate (25-33) & 76 & 69.09 \\
\hline High $(>33)$ & 16 & 14.55 \\
\hline \multicolumn{3}{|l|}{ Achievement motivation } \\
\hline Low (up to 21) & 19 & 17.27 \\
\hline Moderate (22-29) & 77 & 70.00 \\
\hline High $(>29)$ & 14 & 12.73 \\
\hline \multicolumn{3}{|l|}{ Innovativeness } \\
\hline Low (up to 22) & 20 & 18.18 \\
\hline Moderate (23-28) & 73 & 66.36 \\
\hline $\operatorname{High}(>28)$ & 17 & 15.46 \\
\hline \multicolumn{3}{|l|}{ Risk taking ability } \\
\hline Low (up to 16) & 21 & 19.09 \\
\hline Moderate (17-26) & 74 & 67.27 \\
\hline $\operatorname{High}(>26)$ & 15 & 13.64 \\
\hline
\end{tabular}

Table 2. Entrepreneurial intention of undergraduate students of agriculture.

\begin{tabular}{llll}
\hline S. N. & Category & Frequency & Percentage \\
\hline 1 & Low (up to 25) & 26 & 23.64 \\
2 & Moderate (26-42) & 65 & 59.09 \\
3 & High $(>42)$ & 19 & 17.27 \\
\hline
\end{tabular}

involved in independent profession. Occupation of the family has a greater influence on the intention of the younger generation in choosing their career options but here very small percentage i.e.14.55 per cent of respondents' family occupation is business. Psychological factor play very crucial role in developing agri-entrpreneurs and results revealed that majority of the respondents (69.09 percent) had moderate level of self-confidence and achievement motivation ( 70 per cent). It was found that majority of the respondents (66.36 per cent) had moderate level of innovativeness and of risk taking ability (67.27 per cent) which indicates that they are having entrepreneurial characteristics at moderate level (Table 1).

Entrepreneurial intention of undergraduate students of agriculture: Entrepreneurial intention of respondents was divided into three categories; viz. low, moderate and high. Data regarding entrepreneurial intention of undergraduate students of agriculture has been presented in the Table 2. Data revealed that majority of the respondents (59.09 per cent) had moderate level of entrepreneurial intention; while 23.64 per cent of the respondents had low entrepreneurial intention and only 17.27 per cent students had high entrepreneurial intention. Total 82.73 per cent respondents were found to be moderate to low category regarding entrepreneurial intention which could be due to the factor that majority of respondents were found to be with low to moderate risk orientation and low to moderate achievement motivation level. It was also found that majority of respondents had low to moderate innovativeness. Entrepreneurial intention was found be low to moderate for majority of respondents which infers that the university has to inculcate achievement motivation, risk taking capability, self-confidence and innovativeness in the students from very first year to develop entrepreneurial intention among the students. The results of the present study are in conformity with the finding of (Movahedi and Fathi, 2011) who also reported that majority of the students of college of agriculture in Bu-Ali Sina University in Iran were interested in pursuing entrepreneurial career. Results of the study revealed that $64.34 \%$ of target students have agreed to entrepreneurship by positive attitude, $23.43 \%$ by neutral attitude, and finally $12.23 \%$ of the students have been disagreed to entrepreneurship by negative attitude.

Davey, Plewa and Struwig (2011) indicated that students from developing/merging economies were more likely to envisage future careers as entrepreneurs and were more positive towards entrepreneurship than their industrialized European counterparts. Giacomin et al. (2011) examined whether differences exist among American, Asian and European students in terms of entrepreneurial intentions and dispositions. Their findings indicated that the entrepreneurial disposition and intentions differ by country, nevertheless that students 
across countries were motivated and/or discouraged by similar variables. Iakovleva, Kolvereid and Stephan (2011) investigated entrepreneurial intentions in developing and developed countries and they exhibited that the students from developing countries had stronger entrepreneurial intentions than those from developed countries.

This accounts for a less number of respondents (23.64 per cent) who had low entrepreneurial intention. This could be due to various factors like students do not possess entrepreneurial skills, lack of risk taking ability and fear of failure etc. One of the possible reasons for low entrepreneurial intention during graduation may be that they do not want to start business after graduation but aim to set up a business at some point in life. Similar results were also found by Urve, et al., 2006 who reported that a considerable number of students of Tallinn University of Technology do not want to start business immediately after graduation, but postpone this for a more distant future.

Entrepreneurial education at tertiary level has become an essential component of many curriculum in private and public sector higher learning institutions. Since future entrepreneurs can be found amongst those who are currently undergoing their educational process at the universities, entrepreneurship education is seen as one of the most effective ways to promote the transition of graduates into the world of entrepreneurship. World class universities and colleges have implemented various postgraduate, undergraduate and diploma courses on small business management and entrepreneurship. In many developing countries the role of entrepreneurship development is more important than that in developed countries so far as the creation of self-employment opportunities and reduction of unemployment is concerned.

\section{Conclusion}

It was concluded that majority of the respondents (59.09 per cent) of College of Agriculture, G.B. Pant University Agriculture and Technology, Pantnagar had moderate level of entrepreneurial intention, while 23.64 per cent of the respondents had low entrepreneurial intention and only 17.27 per cent students had high entrepreneurial intention. In general, a career as an entrepreneur seems to be appropriate to satisfy the motives like to achieve something and earn a higher income. Students' entrepreneurial intention and knowledge of entrepreneurship are likely to shape their inclination to start their own businesses in the future. It is the first step to make their mind to become an entre- preneur. This type of study will also help universities and other institutions to develop suitable educational programs to promote entrepreneurship programme that can help in generating more interest of undergraduate students to start their enterprise after completing their studies.

\section{REFERENCES}

Davey, T., Plewa, C. and Struwig, M. (2011). Entrepreneurship perceptions and career intentions of international students. Education + Training, 53(5):335-352

Fatoki, Olawale Olufunso. (2010). Graduate Entrepreneurial Intention in South Africa: Motivations and Obstacles. International Journal of Business and Management. 5 (9): 87-98

Giacomin, O., Janssen, F., Pruett, M., Shinnar, R. S., Llopis, F. and Toney, B. (2011). Entrepreneurial intentions, motivations and barriers: Differences among American, Asian and European students. International Entrepreneurship and Management Journal, 7(2):219-238

Iakovleva, T., Kolvereid, L. and Stephan, U. (2011). Entrepreneurial intentions in developing and developed countries. Education + Training, 53(5): 353-370

Indian Applied Manpower Research (IAMR). (2001). Cited in Detailed Project Report of the National Agricultural Education Project (NAEP) ICAR Education Division. 2012. Department of Agricultural Research and Education

International Labour Office (ILO) (2013). Global Youth Unemployment Trends

Kothari, C.R. (1990). Research methodology: Methods and Techniques. New Age International, Delhi

Mali, D.D. (2000). Entrepreneurship through microfinance in North East India: A comprehensive review of existing literature. Information Management \& Business Review, 4(4):168-184

Movahedi, R. and Charkhtabian, T. (2013). Identifying entrepreneurship abilities in agricultural extension and education specialized credits. International Journal of Agriculture and Crop Sciences, 5 (23): 2845-2851

Movahedi, Reza and Fathi Hadi. (2011). Assessing Agricultural Students' Attitude Towards Entrepreneurship. International Journal of Agriculture: Research and Review. Vol., 1 (4):168-173

NYP (2012). Government of India, Ministry of youth affairs and sports. Draft National youth policy

Shiri, N., Mohammadi, D. and Hosseini, S.M. (2012). Entrepreneurial intention of agricultural students: effects of role model, social support, social norms and perceived desirability. Archives of Applied Science Research, 4 (2):892-897

Urve, V., Kolbe E. and Toomas, P. (2006). Students' attitudes and intentions toward entrepreneurship at Tallinn University of Technology", working paper, School of Economics and Business Administration, Tallinn University of Technology (TUTWPE), 97-114 